\title{
Re-balancing artists' rights in cell phone ringtones? An analysis of Tanzanian copyright
}

\author{
Alex B. Makulilo*
}

\section{Cell phones: some facts and figures}

Cell phone ringtones have produced new challenges to copyright law. From the 1990s, and particularly in the 2000s, cell phone ringtones have been big business in the music industry across the globe. Although there are conflicting figures on the precise income derived from the ringtone business, it is undeniable that much revenue is generated from it. To mention some current figures: it is estimated that cell phone ringtone business accounts for a little over 10 per cent of world-wide music sales. ${ }^{1}$ While this sounds good news to artists, the sharing of such revenue has sparked controversies over copyright laws. In the Unites States, the battle over revenue from cell phone ringtone business culminated in the landmark case of In re Cellco Partnership. ${ }^{2}$ Similar suits have been considered by courts elsewhere. In East Africa, Kenya has so far tested the application of its copyright legislation to cell phone ringtones in court, in cases that include Alternative Media Limited $v$ Safaricom Limited, ${ }^{3}$ Cellulant Kenya Ltd $v$ Music Copyright Society of Kenya Ltd, ${ }^{4}$ and Music Copyright Society of Kenya Ltd $v$ Safaricom Limited and another. ${ }^{5}$ In Uganda, the ex-mayor of Kampala, Al Haji Nasser Ntege Sebaggala has sued the giant MTN Uganda Limited, claiming it has infringed his copyright by using his speeches as ringtones without his authorization. ${ }^{6}$ This suit, filed in the Commercial Court in Kampala on 13 July 2012, is pending.

This article focuses on copyright issues emanating from the business of cell phone ringtone in the Tanzanian context. Discussion and analyses are delimited to the Tanzanian Copyright Act and its regulations. Where necessary, case law from other jurisdictions is persuasively referred since there is currently no such case law in existence from the Tanzanian courts.

* Email: alex.makulilo@out.ac.tz.

1 Grigoriy Anoshenko 'Average Revenues That Mobile Ringtones Make Worldwide' Street Directory.com Singapore Guide. Available at http://www. streetdirectory.com/travel_guide/133099/phones/average_revenues_that_ mobile_ringtones_make_worldwide.html (accessed 12 April 2013).

2 In re Cellco Partnership d/b/a Verizon Wireless, Case Nos 09-cv-07074 \& 41 Civ 1395 (SDNY 14 October 2009).

3 Civil Case No 263 of 2004 Alternative Media Limited v Safaricom Limited [2005] eKLR. Available at www.kenyanlaw.org.

4 Civil Case 154 of 2009 Cellulant Kenya Ltd v Music Copyright Society of Kenya Ltd [2009] eKLR. Available at www.kenyanlaw.org.

\section{The author}

- Alex B. Makulilo is a Lecturer in the Faculty of Law at the Open University of Tanzania.

\section{This article}

- The aim of this article is to analyse copyright issues arising from the use of musical works as cell phone ringtones in the Tanzanian music industry.

- The point of departure for discussion is the Copyright and Neighbouring Rights Act, Cap 218 R. E 2002.

- The author argues that business practice does not correspond to the provisions of this Act in the context of cell phone ringtones. As a result, Tanzanian artists and the government lose revenue.

\section{The problem}

On 23 July 2012, The Citizen, a Tanzanian local newspaper, bore an appealing headline, 'How Bongo artists miss billions in ringtone deals. ${ }^{7}$ The paper reported that OnMobile, a foreign company headquartered in Bangalore, India, provided ringtone services for the two major mobile service providers, Vodacom Tanzania and Airtel. However, OnMobile had contractual arrangements with Push Mobile, a local company in Tanzania. The latter signed contracts with artists to obtain licences to use their songs as cell phone ringtones. According to the paper, in the period before OnMobile came on to the scene, particularly in the late 2000s, artists had to deal with either Push Mobile or Spice, both local companies, if they wanted sell their songs as ringtones; this ceased to

5 Civil Case 509 of 2009 Music Copyright Society of Kenya Ltd v Safaricom Limited and another [2010] eKLR. Available at www.kenyanlaw.org.

6 Andante Okanya, 'Ex-mayor Sebaggala sues MTN over ringtones', New Vision, 18 July 2012, http://www.newvision.co.ug/news/633085-ex-mayornasser-sebaggala-sues-mtn-over-ringtones.html (accessed 22 April 2013).

7 Edward Qorro, 'How Bongo artistes miss billions in ringtones deal', The Citizen, Monday, 23 July 2012, http://www.thecitizen.co.tz/component/ content/article/37-tanzania-top-news-story/24246-how-bongo-artistesmiss-billions-in-ringtones-deal.html (accessed 22 April 2013). 
be the case following the arrival of OnMobile. Further, The Citizen reported, out of the cell phone ringtone business in which a ringtone costs 300 Tanzanian shillings (approximately US\$0.19), Vodacom Tanzania and Airtel earned a total of 80 million Tanzanian shillings per day (approximately US\$ 50,777), of which the two mobile firms retained between 75 and 80 per cent. The rest was paid to OnMobile. It was further reported that, after Push Mobile had received its share from OnMobile, it retained everything, leaving only 7 per cent to the artists. On another occasion, Push Mobile admitted that copyright had always been an issue in the music industry. ${ }^{8}$ Also, on monitoring sales of ringtone by mobile phone companies, Push Mobile said it provided artists with viewer accounts where they could see how many songs had been sold and how much they earned. $^{9}$

On 24 July 2012, ringtones were at the centre of the Parliamentary budget session for the 2012/2013 fiscal year. Kigoma North Constituency Representative Zitto Kabwe accused the mobile service companies and agent ringtone providers of 'stealing' from artists. It was Kabwe's submission that the act of under-paying artists their royalties amounted to stealing their copyright works. ${ }^{10}$ He suggested that the proceeds should have been shared fifty-fifty between artists and mobile service companies. ${ }^{11}$

In a move to reorient their position, on 1 August 2012, artists collected 127 signatures and petitioned to cancel all existing contracts with companies initially authorized to deal with their songs. ${ }^{12}$ The companies targeted in the petition were Push Mobile, Crystal and Spice, which either directly or indirectly (through OnMobile) contracted with telecom companies Vodacom, Airtel, Zantel and Tigo. Part of the petition read as follows:

We, the artists of Tanzania in unison irrespective of the genre, instruct you to stop any further sale of our music in terms of caller tunes and ringtones to mobile phone companies. $^{13}$

Through a hired law firm, Trustworthy Attorneys, the artists served seven-day demand letters to Push Mobile,

8 Christine Chacha, 'Are ringtones the new avenue to market music?', The Citizen, Friday, 19 March 2010, 4.

9 Ibid.

10 See, Bunge la Tanzania, Majadiliano ya Bunge, Mkutano wa Nane, Kikao cha Thelathini na Moja-Tarehe 24 Julai, 2012 (The Parliament of Tanzania, Hansard, 24 July 2012); see also Edson Kamukara, 'Zitto ataja wizi kampuni za simu’ Tanzania Daima, Alhamis, 26 July 2012, available at http ://www.freemedia.co.tz/daima/habari.php?id=38583 (accessed 22 April 2013).

11 Ibid.
Crystal and Spice to cancel their contracts with those companies on the basis of 'unfair dealings.' ${ }^{14}$

Apart from big telecom companies and ringtone providers, the ringtone issue has implicated individuals. Two years ago, in Mwananchi, a sister paper of The Citizen, Mr Festo Plea, a columnist, authored an article with a headline, 'COSOTA mnalijua hili la walanguzi wa Kariakoo?' translated in English as 'COSOTA do you know the pirates at Kariakoo? ${ }^{15}$ According to the columnist, pirates were operating openly at Kariakoo, the largest market in Dar es Salaam and the biggest business centre in Tanzania, burning CDs containing artists' copyright works. The pirates were also illegally downloading artists' songs and transferring them into end users' cell phones to be used as ringtones. This ringtone business earned the pirates between 2,500 and 3,000 Tanzanian Shillings (around US\$1.58 to US\$1.89) for each song.

Interviews held between Nassibu Juma, alias 'Diamond' and Ally Kiba (both prominent artists in Tanzania), on the one hand, and the author of this article, on the other ${ }^{16}$ raised a number of legal and practical issues:

- Both artists confirmed they had, or continued to have, contracts with Push Mobile, Crystal and Spice on use of their songs as ringtones.

- These contracts were based on negotiations which took into account a number of factors, such as the popularity of the artist and his songs.

- Those contracts were usually for an indefinite period in which the artists received monthly royalties from sales of their songs.

- The two artists complained that they were not in a position to monitor sales of their songs and were denied monthly financial statements by the companies according to their contracts.

- Because they were not in a position to monitor sales of their songs, they suspected that what they received as royalties was little compared to the huge revenues earned by the companies.

- Asked why they bypassed the Copyright Society of Tanzania (COSOTA), Tanzania's collecting society, in their ringtone deals, the two replied that, although

12 Paul Owere, 'Artistes sever business with mobile firm' The Citizen, Wednesday, 1 August 2012, pp. 1-2. Available at http://www.thecitizen.co. tz/news/4-national-news/24520-artistes-sever-business-with-mobile-firm. html (accessed 22 April 2013).

13 Ibid.

14 Ibid.

15 Festo Plea, 'COSOTA mnalijua hili la walanguzi wa Kariakoo?' Mwananchi, Jumamosi, 21 August 2010, 6.

16 Telephone interview with Nassibu Juma alias 'Diamond' and Ally Kiba, 1 August 2012. 
they were members of the society, which should administer their works in the ringtone deals and others, COSOTA failed to discharge its mandate.

- The two artists maintained that there were many pirates across the country who sold their songs illegally as ringtones.

This background raises a number of copyright questions. First, what copyright subsists in customized cell phone ringtones? Secondly, who has what right in the copyright of cell phone ringtones? Thirdly, to what quantum of royalties are right holders entitled? Finally, who has standing to enforce ringtone contracts? These questions are considered in the following sections of this article.

\section{Copyright in ringtones}

In contrast with traditional ringtones which are supplied with cell phones by their manufacturers, customized cell phone ringtones in Tanzania are largely the songs of Bongo Flava (contemporary urban youth music) artists. Copyright subsisting in these ringtones is no different from ordinary copyright protection in any other musical recording, comprising an underlying musical work and a sound recording which are protected under ss 5(2)(d) and 32(1) of the Copyright Act respectively. This type of copyright protection in Tanzania is similar to that afforded in South Africa, the United Kingdom, the United States of America and Jordan. ${ }^{17}$ Case law in these jurisdictions to date may offer persuasive authorities to Tanzanian courts when faced with similar legal questions.

The Copyright Act, however, defines neither 'musical work' nor 'sound recording. Some authorities have attempted to define 'musical work' as consisting of the musical notes and lyrics (if any) in a musical composition. ${ }^{18}$ The UK Copyright, Designs and Patents Act 1988 defines 'musical work' as a work consisting of music, exclusive of any words or action intended to be sung, spoken or performed with the music. ${ }^{19}$ In other words, 'musical work' under UK law consists of only musical notation (composition) without lyrics. As to 'sound recording' the UK Copyright, Designs and Patents Act 1988 defines it as (a) a recording of sounds, from which the sounds may be reproduced, or (b) a

17 See eg Ramzi Madi 'Copyright Issues in Mobile Phone Ringtones in General and in the Light of the Jordanian Copyright Protection Law' (2012) 18(3) Computer and Telecommunications Law Review 1; O Oluwole Popoola and Maurice T Vambe 'Copyright Protection of Ringtones in South Africa' (2008) 5(2) Muziki: Journal of Music Research in Africa 323; Daniel M Simon 'Cellphone Ringtones: A Case Study Exemplifying the Complexities of the s. 115 Mechanical License of the Copyright Act of 1976' (2008) 57(6) Duke Law Journal 1865; Jennifer Mariano Porter recording of the whole or any part of a literary, dramatic or musical work, from which sounds reproducing the work or part may be produced. ${ }^{20}$ The question whether the Tanzanian courts are ready to read these definitions into the Copyright Act cannot be answered until litigation involving the meanings of such terminologies arises.

\section{Rights and owners of rights in ringtones}

As mentioned, there are two layers of copyright in a musical recording: the underlying musical work and sound recording. Accordingly, there may be more than one owner of a copyright to a cell phone ringtone with different rights depending on what one owns. In an underlying song there are usually two persons who own distinct copyrights: first, there is the lyrist who owns the lyrics in a composition. Secondly, there is the composer who owns the music or musical notes. Sometimes it is possible for one person to be both the lyrist and composer of an underlying musical composition. Each such author enjoys copyright as an author under s 5(2)(d) of the Copyright Act. Yet a composer has to obtain a licence from a lyricist if he or she wants to avoid copyright infringement. Importantly, as owners of copyright, both the lyrist and the composer have exclusive economic and moral rights under ss 9(1) and 11 of the Copyright Act respectively.

Similarly, there are persons who, though not part of the underlying musical composition, perform musical works: these performers (eg singers, musicians, dancers and actors) hold a range of rights under s 31 of the Copyright Act. Under this provision, performers have exclusive rights slightly different from those of authors of copyright works under $\mathrm{s} 5$ of the Act.

The second important component of a musical recording is the sound recording. Its author is the record producer. ${ }^{21}$ In order to avoid copyright infringement, the record producer must obtain a licence from the performer. ${ }^{22}$ Section 31(1) of the Copyright Act grants the producer of a sound recording exclusive economic rights.

There is one further group which generally benefits from copyright-protected cell phone ringtones, and which acquires rights through contractual arrangements

\footnotetext{
'Compulsory Licensing and Cellphone Ringtones: The Phone is Ringing, A Court Needs to Answer' (2008) 80(3) Temple Law Journal 907.

18 See eg IT Law Wiki, http://itlaw.wikia.com/wiki/Musical_work (accessed 22 April 2013).

19 UK Copyright, Designs and Patents Act 1988, s 3(1)(d).

20 Ibid, s 5A(1).

21 The Tanzanian Copyright Act, ss 32(1).
}

22 Ibid, ss 31(1)(b) and 33(1). 
with copyright owners: this group includes telecom companies (eg Vodacom Tanzania, Airtel, Zantel and Tigo), ringtone providers (eg OnMobile, Push Mobile, Crystal and Spice) and end users. Sometimes the providers of ringtones do not have any contractual arrangements with copyright holders, as is the case, for example, with pirates operating at Kariakoo who illegally transfer artists' ringtones into end users' mobile phones. End users have rights of use of copyright works upon payment of a fee per each downloaded song.

\section{Licence and royalties}

In Tanzania, an individual artist may license copyright for use of his or her musical works as ringtones. Quite often artists and ringtone providers bypass COSOTA. This approach may violate Regulation 3 of the Copyright (Licensing of Public Performances and Broadcasting) Regulations 2003, which provides that no person shall hold a public performance of or broadcast a work in which a copyright subsists except under a licence issued by COSOTA. This is, however, subject to one qualification: Regulation 3 concerns only artists who are members of COSOTA. The same Regulation, incidentally, binds ringtone providers.

Why bypass COSOTA, especially if you have registered yourself and your works with the society? The reason always given is that COSOTA has failed to administer exploitation of artists' works. ${ }^{23}$ As for ringtone providers, it is taken for granted that an individual artist has private autonomy of dealing with his or her copyright work.

In Kenya, in Music Copyright Society of Kenya Ltd $v$ Parklands Shade Hotel Ltd T/A Klub House, ${ }^{24}$ the High Court took the view that the Music Copyright Society of Kenya was not entitled to claim to be the sole licensed authority which enforces copyrights of all musical works. ${ }^{25}$ Instead, only the owner of the copyrights had a right to enforce compliance. ${ }^{26}$ However, in Cellulant Kenya Ltd the same court took the opposite view, holding that:

the collecting society on behalf of the music artists had the authority to deal with the plaintiff in regard to the music that the plaintiff converted into ringtones, ${ }^{27}$

adding that:

\footnotetext{
23 Telephone interview, above $\mathrm{n} 16$.

24 Civil Case 1458 of 2000 Music Copyright Society of Kenya Ltd v Parklands Shade Hotel Ltd T/A Klub House [2000] eKLR, http://www. kenyalaw.org/CaseSearch/case_search_ one.php?pageNum_result $=5550$ \&totalRows_result $=72834 \&$ casCourt=High+Court (accessed 22 April 2013).

25 Ibid, 6.
}

the plaintiff, irrespective of whether it entered into individual agreements with the music artists, it is required in law to deal with their legal representative i.e. the defendant (Music Copyright Society of Kenya Ltd) ${ }^{28}$

In its reasoning, the court first noted that the Copyright Act does not specifically prohibit any party from entering into an individual agreement with a copyright owner. Nonetheless, it ruled that the law deemed it necessary for a society to be established for the purposes of coordinating and administering the collection of royalties from persons who have been licensed by the copyright owners to exploit the copyright. Secondly, such a society would possess the expertise and means of monitoring copyright users for the purposes of assessing the quantum of royalties to be paid to individual copyright owners.

Taking the two Kenyan cases in the Tanzanian context, Cellulant Kenya Ltd is highly persuasive for two reasons. First, COSOTA is a statutory body established under the Copyright Act with a function, among other things, of administering exploitation of copyrights works. Administration for this purpose includes collecting and distributing any royalties or other remuneration accorded to artists in respect of their rights under the Act. Secondly, Regulation 3 of the Copyright (Licensing of Public Performances and Broadcasting) Regulations 2003 prohibits holding a public performance or broadcasting of a work in which a copyright subsists except under a licence issued by the COSOTA. Thus ringtone deals between artists and ringtone providers or telecom companies are open to legal challenge.

The other controversial issue arising here relates to copyright remuneration. Generally, this is a matter of contract between copyright holders and users or licensees. As mentioned, the governing principle is that general rules of the law of contracts apply in all questions relating to contracts for use of authors' works. ${ }^{29}$ In Tanzania, rules of law of contracts are generally laid down in the Law of Contract Act. ${ }^{30}$ For the sale of goods, special rules of contract are laid down in the Sales of Goods Act. ${ }^{31}$ Since Tanzania follows the English common law system, common law rules as well as doctrines of equity relating to contracts provide another source of contract law. However, the Copyright Act provides for special

\footnotetext{
26 Ibid.

27 Cellulant, above, n 4, 7.

28 Ibid.

29 The Copyright Act, s 22.

30 Cap 345 R.E 2002.

31 Cap 215 R.E 2002.
} 
rules of copyright contracts too. ${ }^{32}$ These prevail over the general rules of contracts. ${ }^{33}$

Under s 10 of the Contract Act, every agreement must be supported by consideration. ${ }^{34}$ Where no such consideration passes, an agreement is void. ${ }^{35}$ The common law rule that consideration need not be adequate but sufficient applies in Tanzania as well. ${ }^{36}$ The overall implication flowing from these rules is that artists cannot simply forgo their right to remuneration for use of their copyright works. Similarly, mere inadequate remuneration for use of copyright works does not make licensing contracts unenforceable. ${ }^{37}$ In other words, the author is entitled to the remuneration agreed to in the licensing contract. In line with this view, for example, s 31(4) of the Copyright Act states clearly that:

nothing in this section shall be construed to deprive performers of the right to agree by contracts on terms and conditions more favourable for them in respect of their performances.

This necessitates sound negotiation skills on the part of authors. In Tanzania, most artists suffer from the lack of such skills. Perhaps it is because of this, and generally to protect the weak bargaining position of artists, that the Copyright Act incorporates a special requirement that the rate of contract remuneration shall be at an equitable level. But, while the 'equitable remuneration' standard is the benchmark rate in the Copyright $\mathrm{Act}^{38}$ this principle applies only ex post ie after discovery of disproportionate remuneration. ${ }^{39}$

While the Copyright Act is silent as to what is 'equitable', s 19 provides that 'equitable remuneration' relates to 'standards generally prevailing in similar cases'. Commentators argue that compensation is equitable if it conforms, at the time of contracting, to what is customary and fair in business, with regard to the type and scope of the permitted uses, in particular their length and timing, as well as to all other circumstances. ${ }^{40}$ As mentioned, claims for 'equitable remuneration' in Tanzania can only

32 Ibid.

33 Ibid.

34 An act or forbearance of one party, or the promise thereof, is the price for which the promise of the other is bought, and the promise thus given for value is enforceable, see Dunlop Pneumatic Tyre Co Ltd $v$ Selfridge \& Co Ltd [1915] AC 847, 855.

35 The Law of Contract Act, s 25(1). However, under ss 25(1)(a), (b) and (c) respectively, a contract may still be valid even if it is not supported by consideration where it is based on account of natural love and affect; it is made to compensate a past voluntary act; or payment for a timed-barred debt.

36 Ibid, s 25(3).

37 However, an agreement made under coercion, undue influence, fraud and misrepresentation (ss 15, 16, 17 and 18 of the Contract Act respectively), is voidable under s 19 of the Contract Act. In contrast, where an agreement is made under mistake, it generally becomes void: s 20(1). be raised under the following conditions set out in s 19 of the Copyright Act. First, where there is a 'gross disproportion' between the remuneration paid to the owner of copyright and the income from its use. Secondly, the claim cannot be waived in advance. Thirdly, the claim cannot be raised after two years following the discovery of circumstances leading to it. Fourthly, the owner of the copyright work may not claim discovery of such circumstances after the lapse of five years.

The legal significance of a claim for equitable remuneration is that, if successfully made, it displaces any contractual arrangement for equitable remuneration. However, in the context of the present practice of ringtone business in Tanzania, it is difficult for artists to enforce claims for equitable remuneration for several reasons. First, there is likely to be a lack of sufficient empirical evidence of disproportionate remuneration: artists do not normally monitor sales of their songs and, as they maintain, ringtone providers and telecom companies do not provide them with statements of accounts. If this is the case, it may be difficult to establish the claim. This factor is exacerbated where ringtone providers and telecom companies fail to provide true records. Secondly, the would-be equitable 'standards generally prevailing in similar cases' are difficult to ascertain in the Tanzanian music market because the Tanzanian music market is highly constrained by rampant piracy. ${ }^{41}$ Moreover, companies as well as individuals involved in music distribution have always undermined the position of artists by underpaying them. ${ }^{42}$ For all these reasons, the 'standards generally prevailing in similar cases' are always contested by artists for being unfavourable on their side.

As stated, the Copyright Act exempts certain uses of copyright works from the requirement to obtain a licence. These generally fall under the provisions relating to free use. In connection with the ringtone business, a controversial question has arisen whether ringtone providers are required to pay royalties for the public performance of ringtones. This question resolves into two

38 Copyright Act, ss 19, 33.

39 Ibid, s 19.

40 Reto M Hilty and Alexander Peukert "Equitable Remuneration” in Copyright Law: The Amended German Copyright Act as a Trap for the Entertainment Industry in the U.S.?' (2004) 22(2) Cardozo Arts \& Entertainment Law Journal 401, 417.

41 See eg Uta Reuster-Jahn and Gabriel Hacke 'The Bongo Flava Industry in Tanzania and Artists' Strategies for Success' Working Paper No 127, Department of Anthropology and African Studies, Gutenberg University, 2011, p 13; 'Lady Jaydee Cries for Fair Play in Music' Daily News, Sunday, 2 August 2010. Available at http://www.dailynews.co.tz/home/?n=12196 (accessed 12 April 2013); 'Jamii isaidie kudhibiti wizi wa sanaa nchini' Mtanzania, Ijumaa, 4 September 2009, 6.

42 A Perulo, The Music Business in Tanzania: Copyright Law, Contracts, and Collective Management Organisation (Dar es Salaam 2005) 21 (English and Swahili). 
further sub-questions. First, does the transmission by downloading of a ringtone to a mobile phone constitute a public performance? Secondly, when a ringtone goes off, does that constitute a public performance? In In re Cellco Partnership, a US decision, both questions were answered in the negative. With regard to the first question, the Court said:

in analysing whether the transmission to a cellular telephone qualifies as a transmission of the work to the public, the focus is on the transmission itself and its potential recipients and not on the potential audience of the underlying work or ringtone. $^{43}$

Since the ringtone could not be played before the transmission was concluded, there was no public performance. ${ }^{44}$ Obiter, the court added:

[E]ven if the customer could listen to the download (which was not the case in the present case) as it was being received, and contemporaneously perceive it as the musical work, that could not constitute a public performance. ${ }^{45}$

As to the second question, the court ruled that when a ringtone goes off-whether in public where other people around may hear it or in private- that is exempted under the performances of a musical work that occur within the 'normal circle of a family and its social acquaintances. ${ }^{46}$ The court focused its analysis around the term 'publicly' in the context of ringtone, which is basically intended to the recipient of the call. It similarly exempted the performance because mobile phone customers do not play the ringtones for any commercial advantage; they receive no fee or compensation for the performances; and they do not charge admission. ${ }^{47}$ This court's decision has generated scholarly debate. Since the Tanzanian Copyright Act maintains similar provisions as the US law on exemption on the basis of private use, the In re Cellco Partnership provides a highly persuasive authority.

\section{Enforcement}

As a general rule, the owner of copyright is the sole person who may enforce compliance with the Copyright Act in case of infringement of his or her rights. However, the right of enforcement is subject to the mandate given to COSOTA by the Copyright Act. Where an artist is a registered member of COSOTA, the latter may enforce the artist's rights. However, under criminal law, COSOTA may be placed in a position to undertake investigation of alleged infringements of the Act, and surrender the culprits to the police for prosecution. Similarly, an artist may lay down information to the police for the same purpose. As things stand at present, the enforcement of the Copyright Act is still challenging for numerous reasons: lack of culture of respect for copyright among the members of public; lack of capacity by COSOTA to go around the country to deal with infringers; lack of understanding of the value of copyright among artists; lack of sufficient technological mechanisms to track copyright infringements; some weakness in the law; lack of sufficient legal and general training of copyright laws - and more.

Meanwhile, enforcement of licensing contracts is limited by the common law principle of privity of contract. This principle requires that only parties to a contract have the rights to enforce it. While the recent petition by artists, comprising 127 signatures, is important, as it sends strong signal to telecom companies and ringtone providers about fair remuneration in exploitation of their musical works as ringtones, it cannot by itself have any force of law to terminate licensing contracts entered by individual artists with the telecom companies or ringtone providers.

\section{A modest proposal}

This article has noted that the ringtone business is sprouting in the Tanzanian music market. However, the exploitation of copyright in the context of this business remains a big challenge. A number of copyright issues have been raised and discussed and unfair remuneration has emerged as a serious concern following The Citizen report. While a number of issues need to be addressed, this article proposes, as a starting point, and with respect to the theme considered here, that in order to re-balance the position of artists and users of copyrightable works, 'common remuneration standards' be developed in order to satisfy the requirement of 'equitable remuneration' envisaged under the Copyright Act. These 'common remuneration standards' must only be minimum standards that may be periodically reviewed when circumstances arise. While these standards may protect the artists' remuneration base, they must be left free to negotiate more favourable deals on their side.
43 In re Cellco Partnership, above, n 2, supra, 15.
44 Ibid, 21.
45 Ibid, 22.
46 Ibid, 23-34.

47 Ibid. 